\title{
Taking European defence seriously: The naval operations of the European Union as a model for a Security and Defence Union*
}

\author{
Tomando la defensa europea en serio: \\ las operaciones navales de la Unión Europea \\ como un modelo para una Unión de Seguridad y Defensa
}

\author{
Carlos Espaliú Berdud \\ Universitat Internacional de Catalunya (Barcelona) \\ cespaliu@uic.es
}

doi: http://dx.doi.org/10.18543/ced-58-2018pp157-183

Summary: I. Introduction.-II. The naval operations of the EU in the frame of the CSDP operations. 1. Operation Atalanta: a traditional CSDP operation, but in the sea. 2. Operation Sophia: a step forward for peace enforcement operations?-III. From the naval operations of the EU to a Security and Defence Union, passing through the Permanent Structured Cooperation. 1. The time for the Permanent Structured Cooperation has come. 2 . Which would be the remaining steps beyond the Permanent Structured Cooperation?-IV. Conclusion.

\begin{abstract}
The two naval operations set up until now by the EU, Atalanta and Sophia, have demonstrated a growing level of consensus and willingness by Member States, a great number of which participating in both operations. Furthermore, and more clearly in the case of Atalanta but also in the first stages of Sophia, it can be said that these CSDP activities have been highly successful, taken into consideration the level of accomplishment of their respective goals. Having shown its potential, the launching of naval operations in crisis management could be seen as a step forward in the creation of a Security and Defence Union. Therefore, the next step in European integration regarding security matters can be the implementation of the Permanent Structured Cooperation anticipated in Article 42.2 and 46 of TEU and developed in Protocol No 10 annexed to the Lisbon Treaty. That achievement would be the landmark that would generate the nucleus from which a Security and Defence Union can emerge.
\end{abstract}

* Recibido el 14 de diciembre de 2017, aceptado el 10 de enero de 2018. This article represents part of the contribution of the author to the research projects: "La seguridad nacional de España: un enfoque geográfico" (Ministerio de Economía y Competitividad, DER-201457671-R) and "Formas contemporáneas de esclavitud y derechos humanos en la era de la globalización” (Ministerio de Economía y Competitividad, DER2014-56417-C3-1-P). 
Keywords: CSDP; Operation Atalanta; Operation Sophia; Security and Defence Union.

Resumen: Las dos operaciones navales que ha puesto en marcha hasta ahora la UE, Atalanta y Sophia, han demostrado un creciente nivel de consenso y voluntad por parte de los Estados Miembros, de los que ha participado un gran número. Además, más claramente en el caso de Atalanta, pero también en los primeros pasos de Sophia, se puede decir que estas dos operaciones de la CSDP están resultando bastante exitosas, en atención al grado de cumplimiento de sus respectivos objetivos. Habiendo demostrado su potencial, el lanzamiento de operaciones navales para la gestión de crisis puede ser visto como un paso hacia la creación de una Unión de Seguridad y Defensa. De esta manera, el paso siguiente en la integración europea en materia de defensa puede ser la implementación de la Cooperación Estructurada Permanente prevista en el artículo 42.2 y 46 del TUE y desarrollada en el protocolo.$^{\circ} 10$ anexado al Tratado de Lisboa. Este logro podría ser el hito que genere el núcleo del que pudiera emerger una Unión de Seguridad y Defensa.

Palabras clave: PCSD; Operación Atalanta; Operación Sophia; Unión de Seguridad y Defensa.

\section{Introduction}

One of the results of the referendum celebrated in the United Kingdom in June 2016 and the subsequent invocation of Article 50 of the Treaty on European Union (TEU) has been that the aim to reach in the future a possible Common Defence or a Security and Defence Union seems now less an impossible and an unattainable utopia, like it was before, partly due to the traditional British opposition to a European integration in defence matters ${ }^{1}$,

1 Indeed, in one of his speeches to prepare the referendum on the 2016 UK's EU membership, the then British Prime Minister, David Cameron, noted that: "Decisions on foreign policy are taken by unanimity. Britain has a veto. So suggestions of an EU army are fanciful: national security is a national competence, and we would veto any suggestion of an EU army", see: David Cameron, PM speech on the UK's strength and security in the EU: 9 May 2016 (Archived), https://www.gov.uk/government/speeches/pm-speech-on-the-uks-strengthand-security-in-the-eu-9-may-2016, page last visited on 11 July 2017. Moreover, a couple of months after the Brexit vote, in early October 2016, in his speech to the Conservative Party conference, Sir Michael Fallon, the British Secretary of State for Defence, clearly underlined that "[L]eaving the EU does not mean we are stepping back from our commitment to the security of our continent. We will continue to have the biggest defence budget in Europemeeting the 2 percent NATO spending target. And we will lead in NATO-the cornerstone of our defence-putting troops on to its eastern border next year. But we will go on blocking 
with the exception probably of the period in which the Labour Party was in power ${ }^{2}$.

In fact, during the Bratislava Summit of 27 Member States of 16 September 2016, the first after the Brexit vote, it was decided, as a priority regarding external security and defence matters, to reinforce the cooperation in the European Union (EU) ${ }^{3}$. Moreover, on 22 November 2016, a non-binding resolution was passed by the European Parliament proposing that all EU Member States should increase their expenditure on military equipment and that the EU should take a more active role with regard to security matters in the world alongside with the North Atlantic Treaty Organization (NATO) or autonomously ${ }^{4}$. Finally, just some weeks ago, on 11 December 2017, the Council of the EU adopted a decision establishing Permanent Structured Cooperation (PESCO) and determining the list of Participating Member States ${ }^{5}$, which represents the first step in the direction of creating a Security and Defence Union.

In this context, and in presence of the two naval operations launched by the EU, Atalanta in 2008 and Sophia in 2015 and their present accomplishments, we can ask ourselves if the EU has finally found a niche where it could become an important military actor or even if these steps could be considered part of a path heading to a Security and Defence Union in the EU.

an EU army, which would simply undermine NATO. We will step up, not away from, our global responsibilities", see: Conservative Party, "Fallon: Our Armed Forces-Delivering Security and Opportunity", 4 October 2016. With regard to the British traditional opposition against European integration and the opportunities that its exit would bring in this field see:Sven Biscop, "The UK and European Defence: Leading or Leaving?", International Affairs, 88 (2012): 1297-1313. For him, in sum, "[a]ssessing the British role in European defence 40 years after accession to the Community, the conclusion is that by leading the CSDP in order to limit it, the UK has manoeuvred itself into a dead end. It has effectively managed to block those dimensions of the CSDP considered contrary to its interests, notably significant autonomous military operations" (ibid., 1297).

2 In this regard see: Sven Biscop, "The UK's change of course: a new chance for the ESDI", European Foreign Affairs Review 4 (1999): 253-268, and John Roper, "Two cheers for Tony Blair? The political realities of European defence cooperation", in Geoffrey Edwards and George Wiessala, eds, The European Union: the Annual Review 1999-2000 (Chichester: Wiley-Blackwell, 2001): 7-23.

${ }^{3}$ European Union, Informal meeting of the 27 heads of state or government, Bratislava Declaration and Roadmap, 16 September 2016.

${ }^{4}$ European Parliament, Defence: MEPs push for more EU cooperation to better protect Europe, Press release of 23 November 2016, see: http://www.europarl.europa.eu/sides/ getDoc.do?type $=I M-P R E S S \&$ reference $=20161117$ IPR51547\&format $=$ PDF\&language $=E N$, page last visited on 7 July 2017.

5 COUNCIL DECISION establishing Permanent Structured Cooperation (PESCO) and determining the list of Participating Member States, see: http://www.consilium.europa.eu/ media/32000/st14866en17.pdf., page last visited on 12 December 2017. 
The moment to carry out this reflection is perfect, because the EU seems to be at a crossroad, at least in respect of security matters. Indeed, next to the Brexit other factors are at work when it comes to put pressure in order to take important decisions. On the one hand, jihadism has already succeeded in placing security matters in the front row among the preoccupations of the Europeans ${ }^{6}$. On the other hand, so as it was warned during the electoral campaign by the future president of the United States of America, Senator Trump, the United States is going to let Europe to take its security in its own hands. Finally, the annexation of Crimea and some recent cybernetic attacks shows that the actual Russian foreign affairs policy is a serious menace for the rest of Europe. In front of these menaces and risks, the European states cannot react unilaterally ${ }^{7}$. Whether we want or not, the necessity of a stronger cooperation, or even an increased integration, in security and defence matters seems to be imperative.

With this aim, I will undertake first the task to deep into the two recent naval operations of the EU in the context of the Common Security and Defence Policy (CSDP) in order to find out their common traits and their differences, as well as their accomplishments. In the light of those experiences, second I will try to foresee the steps that lie ahead in the way if we want to move forward from the CSDP to a Security and Defence Union, starting by the implementation of the PESCO. Then I will present my conclusion.

${ }^{6}$ According to the results of the Standard Eurobarometer survey published on 22 December 2016, Europeans see terrorism as one of the major challenges that is facing the EU in the present time, see: European Commission, Press release, Autumn 2016 Standard Eurobarometer: Immigration and terrorism continue to be seen as the most important issues facing the EU, Brussels, 22 December 2016.

7 According to a recent report published by the EU Institute for Security Studies: "No single European country is able to manage the violent conflicts, hybrid warfare challenges and sophisticated cyberattacks now taking place in and around Europe on its own. The world's deteriorating security environment is pushing states towards an international division of labour in the provision of crisis management and military security. As a result, the pressure increases on Europe to do more on defence. With national budgets under strain, it is increasingly accepted that intensified military integration is the only way forward if Europe is to play a meaningful military role in its own immediate neighbourhood, let alone on the global stage". See: Jan Joel Andersson, Sven Biscop, Bastian Giegerich, Christian Mölling, Thierry Tardy, "Future V: European army", in Envisioning European Defence: five futures, Chaillot Papers 137, EU Institute for Security Studies, (2016): 31 . 


\section{The naval operations of the $\mathrm{EU}$ in the frame of the CSDP operations}

The Lisbon Treaty gave a decisive impulse for the development of the $\mathrm{CSDP}^{8}$. Among other things, the treaty included both a mutual assistance and a solidarity clause and allowed for the creation of the European External Action Service under the authority of the High Representative of the Union for Foreign Affairs \& Security Policy, who is at the same time Vice-President of the European Commission and President of the Foreign Affairs Council. These double functions of the newly created post give the High Representative the possibility to bring all the necessary EU assets together and to apply a "comprehensive approach" to EU crisis management ${ }^{9}$, a field on which the Lisbon Treaty had also a significant impact.

Other novelties of the Lisbon Treaty include the creation of the PESCO and the reform of the rules governing the financing of the CSDP activities ${ }^{10}$. The crisis management was already an important field in the EU's external action wherein it has achieved a certain level of efficiency in the international context. Indeed, since the creation of the European Union Police Mission in Bosnia and Herzegovina by Council Joint Action 2002/210/CFSP of 11 March 2002 ${ }^{11}$, some 30 civilian and military missions and operations ${ }^{12}$ have been launched under the CSDP. These are, in turn, part of different, broader international peace operations carried out

${ }^{8}$ For a comprehensive history of the CSDP evolution, see: André Dumoulin, "Héritages et stimulants à la courte histoire de la PESD/PSDC", in L'autonomie stratégique de l'Union européenne : perspectives, responsabilité, ambitions et limites de la défense européenne, ed. by Nicola Clinchamps and Pierre-Yves Monjal (Bruxelles: Larcier, 2015), 31-44; Alberto Herrero de la Fuente y María Corral Suárez, "La contribución de la Unión Europea al mantenimiento de la paz y de la seguridad internacionales", in La acción colectiva del uso de la fuerza : nuevos escenarios, "nuevos" principios de actuación en el orden internacional, ed. por Consuelo Ramón Chornet (Valencia: Tirant lo Blanch, 2012), 281-308, and Panos Koutrakos, The EU Common Security and Defence Policy (Oxford: Oxford University Press, 2013), 5-78.

9 According to Thierry Tardy, "In broad terms, crisis management is about preventing a crisis from occurring, responding to an ongoing crisis, or assisting in the consolidation of peace (or order) once the acute phase of a crisis has passed. It is not necessarily per se about conflict resolution". See: Thierry Tardy, "A complex environment", in CSDP in action What contribution to International Security?, ed. by Thierry Tardy, Chaillot Papers 134, EU Institute for Security Studies, (2015): 9.

${ }_{10}$ On this aspect, see: Koutrakos, The EU Common Security...76-78.

11 Council Joint Action of 11 March 2002 on the European Union Police Mission (OJEC L 070, 13 March 2002).

${ }^{12}$ In the CSDP vocabulary, military activities are called 'operations' while civilian activities are called 'missions'. 
under different flags - in particular, the United Nations (UN) and NATO, since the end of the Cold War in diverse regions of the World ${ }^{13}$.

At present, the CSDP is regulated in Section 2, of Chapter $2^{14}$, of Title V TEU ${ }^{15}$. According to Article 42.(1) TEU, CSDP "[...] shall provide the Union with an operational capacity drawing on civilian and military assets", which can be used "[...] on missions outside the Union for peace-keeping, conflict prevention and strengthening international security in accordance with the principles of the United Nations Charter". The kind and nature of CSDP operations are further specified in Article 43.(1) TEU, which refers to "joint disarmament operations, humanitarian and rescue tasks, military advice and assistance tasks, conflict prevention and peace-keeping tasks, tasks of combat forces in crisis management, including peace-making and postconflict stabilisation." This provision further states that "[...] All these tasks may contribute to the fight against terrorism, including by supporting third countries in combating terrorism in their territories".

Among the CSDP operations, were the two, approved naval operations Atalanta and Sophia that we are going to present now.

\section{Operation Atalanta: a traditional CSDP operation, but in the sea}

Since the year 2005, the International Maritime Organization (IMO) reported a worrying increase in the number of acts of piracy and armed robbery against ships in waters off the coast of Somalia. Concerned about the problem, on 23 November 2005 the IMO Assembly unanimously adopted resolution A. 979(24) aimed at raising the level of awareness of the scenario in that part of Africa and encouraging action to remedy the situation. The IMO Assembly authorized the IMO Secretary-General to submit the resolution, along with any further action he might deem appropriate, to the Secretary-General of the UN for consideration, additionally authorizing him/ her to bring the matter to the attention of the United Nations Security Council (UNSC), which began, thereafter, to get involved in the matter ${ }^{16}$.

13 See on this point: Antonio Missiroli, "Foreword", in CSDP in action -What contribution to International Security?, ed. by Thierry Tardy, Chaillot Papers 134, EU Institute for Security Studies, (2015): 5.

14 (SPECIFIC PROVISIONS ON THE COMMON FOREIGN AND SECURITY POLICY).

15 (GENERAL PROVISIONS ON THE UNION'S EXTERNAL ACTION AND SPECIFIC PROVISIONS ON THE COMMON FOREIGN AND SECURITY POLICY).

16 The Security Council had been already concerned about the global situation in Somalia since 1992, when it approved the Resolution 733 (1992), of 23 January 1992, implementing an arms embargo on Somalia. See: U.N. Doc. S/RES/733 (1992). 
It was by the authority of Resolution $1772(2007)^{17}$ that the Security Council proceeded to adopt measures under Chapter VII of UN Charter. Initially, those measures were in accordance with the general international law applicable to the fight against maritime piracy. Nonetheless, afterwards, taking into account the inefficacy of those initial measures the Security Council changed its strategy and adopted new measures that were more innovative and stronger ${ }^{18}$.

Of particular relevance is Resolution 1816 (2008), adopted on 2 June 2008. This authorized third States to enter the territorial waters of Somalia for the purpose of repressing acts of piracy and armed robbery at sea, and furthermore, entrusted them with the power to use, within the territorial waters of Somalia, all necessary means to repress acts of piracy and armed robbery, which implies a substitution of the coastal State ${ }^{19}$. Even more important than that was the acknowledgement by the Security Council that the only previous authorization of anti-piracy campaigns in the region had been provided following receipt of the letter from the Permanent Representative of the Somalia Republic to the UN to the President of the Security Council dated 27 February 2008 conveying the consent of the Transitional Federal Government ${ }^{20}$.

In face of the number and danger of the pirate attacks, the Council has had to prolong in time those measures adopting new resolutions ${ }^{21}$.

Some months later, the EU answered positively to the UNSC's call on States and regional organisations to take action to protect shipping involved either in the transport and delivery of humanitarian aid to Somalia brought by the World Food Programme (WFP) or in the transport of the logistic for the peace keeping operation of the African Union Mission in Somalia (AMISOM) 22 . Therefore, by its Joint Action 2008/851/CFSP, adopted on 10 November 2008, the Council of the EU

17 Security Council Resolution 1772 (2007) of 20 August 2007, U.N. Doc. S/RES/1772 (2007).

${ }^{18}$ In that sense see: Carlos Espaliú Berdud, "La operación Atalanta de la Unión Europea en el marco de la lucha contra la piratería marítima", Revista de las Cortes Generales 79, (2010): 146.

${ }^{19}$ Security Council Resolution 1816 (2008) of 2 June 2008, U.N. Doc. S/RES/1816 (2008), para. 7.

20 Ibid., para. 9.

${ }^{21}$ See Resolutions 1846 (2008); 1851 (2008); 1897 (2009); 1950 (2010); 2020 (2011); 2077 (2012); 2125 (2013); 2184 (2014); 2246 (2015) and 2316 (2016).

22 AMISOM is a regional peacekeeping mission operated by the African Union with the approval of the UN, created by the African Union's Peace and Security Council on 19th January 2007. In that sense see: http://amisom-au.org/amisom-background, page last visited on 7 July 2017. 
set up a military operation, called Atalanta (EU NAVFOR) ${ }^{23}$, in order to provide, firstly, for the protection of vessels of maritime convoys of the WFP; secondly, for the protection of vulnerable vessels cruising off the Somali coast; and thirdly, for the deterrence, prevention and repression of acts of piracy and armed robbery off the Somali coast, in accordance with the mandate laid down in UNSC Resolution $1816(2008)^{24}$. The Council of the EU unambiguously stressed that the measures adopted would respect the conditions set by the relevant international law and by UNSC Resolutions on the matter ${ }^{25}$. Furthermore, the Council of the EU decided that the forces deployed to that end should operate up to 500 nautical miles off the Somali coast and neighboring countries ${ }^{26}$. Moreover, in view to the prosecution of the persons arrested and detained during the naval operation, the Council of the EU settled the jurisdiction of the flag Member State or of the third State participating in the operation ${ }^{27}$, of the vessel which took them captive, or, if that State could not, or did not wish to, exercise its jurisdiction, to a Member State or any third State which wished to exercise its jurisdiction ${ }^{28}$. In any case of apprehension, it was decided to guarantee in particular that no

${ }^{23}$ Joint Action 2008/851/CFSP of 10 November 2008 on a European Union military operation to contribute to the deterrence, prevention and repression of acts of piracy and armed robbery off the Somali coast (OJEU L 301/33, 12 November 2008). For an extended report of the subsequent measures adopted by the EU that ended up with the Joint Action 2008/851/CFSP see: Giuseppe Massetti and Fulvia Orsini, La Missione Atalanta e la politica estera dell'Unione Europea. Entrata in vigore del Trattato di Lisbona, azione esterna e capacità di proiezione navale (Roma: Aracne editicre, 2010), 70-74.

${ }^{24}$ Article 1. 1. Joint Action 2008/851/CFSP of 10 November 2008 on a European Union military operation to contribute to the deterrence, prevention and repression of acts of piracy and armed robbery off the Somali coast (OJEU L 301/33, 12 November 2008).

25 Ibid. Article 2.

26 Ibid. Article 1.2. In fact, the Atalanta naval operation has been operating in an area covering the Somali coastal territory, as well as its territorial and internal waters; the Southern Red Sea, the Gulf of Aden and a large part of the Indian Ocean, including the Seychelles, Mauritius and Comoros.

${ }^{27}$ On the request of UN, in late 2008, NATO started to provide escorts to WFP vessels in the zone of the Gulf of Aden. Those activities evolved in August 2009 in Operation Ocean Shield contributing to providing maritime security in the region, in full complementarity with the relevant UN Security Council Resolutions and in coordination with other counterpiracy initiatives such as the European Union's Atalanta, the US Combined Task Force 151 (CTF-151) and deployments from individual countries such as China, India and South Korea. See in this respect: NATO, Counter-piracy operations: http://www.nato.int/cps/en/natohq/ topics_48815.htm, page last visited on 7 July 2017.

${ }_{28}$ Article 12.1 Joint Action 2008/851/CFSP of 10 November 2008 on a European Union military operation to contribute to the deterrence, prevention and repression of acts of piracy and armed robbery off the Somali coast (OJEU L 301/33, 12 November 2008). 
one should be subjected to the death penalty, to torture or to any cruel, inhuman or degrading treatment ${ }^{29}$.

In the light of experience from the first months of the operation, by the subsequent Council Decision 2009/907/CFSP of 8 December 2009, amendments to Joint Action 2008/851/CFSP were introduced in order to allow for the EU naval force to contribute to the monitoring of fishing activities off the coast of Somalia ${ }^{30}$. Furthermore, on 23 March 2012, by the Council Decision 2012/174/CFSP, the area of operations of Atalanta was extended to include Somali internal waters and Somali land territory ${ }^{31}$. The extension to the land territory of Somalia was based on the UNSC Resolution 851/2008, which enabled States and regional organizations cooperating in the fight against piracy and armed robbery at sea off the coast of Somalia to undertake all necessary measures that were appropriate in Somalia, for the purpose of suppressing acts of piracy and armed robbery at sea, pursuant to the request of the Transitional Federal Government of Somalia ${ }^{32}$. This change allowed the EUNAVFOR Somalia, in May 2012, to attack Somali pirate assets on land for the first time since the beginning of the operation, in response to the previous hijacking of a Greek-owned oil tanker carrying crude oil ${ }^{33}$.

When it comes to the point of weighing the results, I agree with Professor Annemarie Peen Rodt according to whom one may accept that an operation can be considered as a success "[...] when its purpose has been achieved and implemented in an appropriate manner from both an EU perspective and a conflict perspective" 34 .

${ }^{29}$ Ibid., Article 12. 2. For the questions of responsibility of the EU regarding the operation Atalanta see: Efthymios Papastavridis, "EUNAVFOR Operation Atalanta off Somalia: The EU in unchartered legal waters?", International and Comparative Law Quarterly 64, (2015): 533-568.

30 Council Decision 2009/907/CFSP of 8 December 2009 amending Joint Action 2008/851/CFSP on a European Union military operation to contribute to the deterrence, prevention and repression of acts of piracy and armed robbery off the Somali coast (OJEU L 322/27, 9 December 2009).

${ }^{31}$ Council Decision 2012/174/CFSP of 23 March 2012 amending Joint Action 2008/851/CFSP on a European Union military operation to contribute to the deterrence, prevention and repression of acts of piracy and armed robbery off the Somali coast ( OJEU L 89/69, 27 March 2012).

32 Security Council Resolution 1851 (2008) of 16 December 2008, U.N. Doc. S/ RES/1851 (2008), para. 6. On this matter see: Raquel Regueiro Dubra, "El uso de la fuerza en el mar y la operación Atalanta de la Unión Europea", in Crisis somalí, piratería e intervención internacional, ed. by Jesús Ramón Bacas Fernández et al. (Madrid: Instituto Universitario General Gutiérrez Mellado, UNED, 2009): 141.

33 See: https://euobserver.com/tickers/116275 (page last accessed on 22 April 2016). On this point see also: Koutrakos, The EU Common Security...122.

34 See: Annemarie Peen Rodt, "EU performance in military conflict management", in The European Union as a Global Conflict Manager, ed. by Richard G. Whitman, and Stefan Wolff (Abingdon: Routledge, 2012): 185. 
In that regard, it is evident that the EU Operation Atalanta has considerably helped in reducing piracy off the Somali coast ${ }^{35}$. If we look at the number of the total attacks ${ }^{36}$, it appears that they have decreased remarkably since the beginning of the operation. In 2009, there were 163 total attacks and in 2016 only one ${ }^{37}$. Since 2009 , a total of 160 pirates have been transferred to competent authorities with a view to their prosecution and 145 have been convicted ${ }^{38}$. It is also worth pointing out that 410 WFP vessels and 139 AMISOM vessels have been protected since the beginning of the operation, allowing 1,483,446 tons of food/aid to be delivered by WFP ${ }^{39}$.

Due to this success, on 21 November 2014 the Council of the EU extended the Mandate of Operation ATALANTA until December 2016, and again, on 28 November 2016 until December $2018^{40}$.

Of particular note, is the level of participation of Member States. It has increased constantly to reach 21 Member States, even if their levels of involvement in number of assets and forces vary considerably. Nevertheless, participation in EU NAVFOR goes beyond EU Member States. Norway was the first non-EU country to contribute to the Operation, with a warship in 2009. Thereafter, Montenegro, Serbia and Ukraine have provided staff officers to the Operational Headquarters (OHQ) and Force Headquarters (FHQ). Ukraine contributed a warship early in 2014, and New Zealand contributed an MPRA asset later the same year ${ }^{41}$.

35 It goes without saying that the decrease of cases of piracy in the zone owes also to other policies and actions of the EU in conjunction with other actors involved in the crisis. On the matter of the political action of the EU see: Giuseppe Massetti and Fulvia Orsini, La Missione Atalanta...84-88. For its part, the UNSC has several times acknowledged the important contribution of the naval operation Atalanta together with other international actors. For instance, in its Resolution 2316 (2016) of 9 November 2016, it stated that "[...] the joint counter-piracy efforts of States, regions, organizations, the maritime industry, the private sector, think tanks and civil society have resulted in a steady decline in pirate attacks as well as hijackings since 2011" (see: Security Council Resolution 2316 (2016) of 9 November 2016, U.N. Doc. S/RES/2316 (2016).

36 Total attack is the combined number of all attacks mounted by suspect pirates; those repelled/aborted and those leading to ships being in pirate hands and crews taken hostage. See in that respect: http://eunavfor.eu/key-facts-and-figures, page last visited on 5 July 2017.

37 Ibid.

38 Ibid.

39 Ibid.

40 See: http://eunavfor.eu/mission/, page last visited on 5 July 2017.

${ }^{41}$ Ibid. 


\section{Operation Sophia: a step forward for peace enforcement operations?}

In April 2015, the EU, in view of the recurrent human tragedies resulting from the smuggling of people across the Mediterranean, confirmed a strong commitment to prevent those atrocities. As a result, on 18 May 2015 the Council of the EU established a European Union military operation in the Southern Central Mediterranean (EUNAVFOR MED, later on called SOPHIA). Its aim was to undertake systematic efforts to identify, capture, and dispose of vessels and assets used or suspected of being used by migrant smugglers or traffickers ${ }^{42}$. The naval operation shall be conducted in sequential phases: in a first phase, already expired, Sophia has supported the detection and monitoring of migration networks through information gathering and patrolling on the high seas in accordance with international law. In a second phase, the naval operation of the EU shall, on the one hand, conduct boarding, search, seizure and diversion on the high seas of vessels suspected of being used for human smuggling or trafficking, under the conditions provided for by applicable international law, including United Nations Convention on the Law of the Sea (UNCLOS) and the Protocol against the Smuggling of Migrants. On the other hand, in accordance with any applicable UNSC Resolution or consent by the coastal State concerned, Sophia shall conduct boarding, search, seizure and diversion, on the high seas or in the territorial and internal waters of that State, of vessels suspected of being used for human smuggling or trafficking, under the conditions set out in that Resolution or consent. Finally, in a third phase, in accordance with any applicable UNSC Resolution or consent by the coastal State concerned, the naval operation shall take all necessary measures against a vessel and related assets. This can include the disposal or confiscation of vessels or assets which are suspected of being used for human smuggling or trafficking, in the territory of that State, under the conditions set out in that Resolution or consent ${ }^{43}$.

The text of the Decision shows a relevant degree of willingness and determination in using the force in accordance with the level taken in the last phase of operation Atalanta after the Council Decision 2012/174/ CFSP of 23 March 2012, which was new in comparison with other military operations undertaken under the umbrella of CSDP. Indeed the Council of the EU authorizes the use of force necessary to render the vessels and

42 COUNCIL DECISION (CFSP) 2015/778 of 18 May 2015 on a European Union military operation in the Southern Central Mediterranean (EUNAVFOR MED) (OJEU L 122, 19 May 2015).

43 Ibid. Article 2. 
enabling assets of the smugglers and traffickers inoperable, if the EU succeeds on getting the necessary UNSC backing or the consent of the coastal State ${ }^{44}$.

The necessary UNSC support came a couple of months afterwards, but only in partial measure. On 9 October 2015 the UNSC adopted its Resolution 2240 by which, acting under Chapter VII of the Charter of the UN, it decided to authorize member States, acting nationally or through regional organizations, to use all measures in confronting migrant smugglers or human trafficking in full compliance with international human rights $\mathrm{law}^{45}$. In fact, the UNSC Resolution authorizes the inspection on the high seas off the coast of Libya of suspect vessels of being used for migrant smuggling or human trafficking from Libya, provided that the States of the regional organisations engaged in the fight against migrant smuggling and human trafficking make good faith efforts to obtain the consent of the vessel's flag State prior to using that authority ${ }^{46}$. The UNSC also authorizes those States and international organisations to seize vessels inspected that are confirmed as being used for migrant smuggling or human trafficking from Libya ${ }^{47}$. Furthermore, the UNSC charges the States and regional organisations authorized with the obligation to "keep flag States informed of actions taken with respect to their vessels". However, at the same time, the Security Council calls upon "flag States that receive such requests to review and respond to them in a rapid and timely manner" 48 . Finally, the UNSC noted that the previous authorisations apply only for the circumstances of the case "and shall not affect the rights or obligations or responsibilities of Member States under international law, including any rights or obligations under UNCLOS, mainly the general principle of exclusive jurisdiction of a flag State over its vessels on the high seas"

It is worth to mention that these authorizations go a little bit further that the provisions of the 2000 Protocol against the Smuggling of Migrants by Land, Sea and Air, supplementing the United Nations Convention against Transnational Organized $\mathrm{Crime}^{50}$, which always

${ }^{44}$ In that sense see also: Thierry Tardy, "Operation Sophia. Tackling the refugee crisis with military means", Brief Issue 30, EU Institute for Security Studies, (2015): 3.

${ }^{45}$ United Nations Security Council, Resolution 2240 (2015) of 9 October 2015, S/ RES/2240 (2015).

46 Ibid., para. 7.

47 Ibid., para. 8.

48 Ibid., para. 9.

49 Ibid., para. 11.

50 The Protocol was adopted by resolution A/RES/55/25 of 15 November 2000 at the fifty-fifth session of the General Assembly of the United Nations. 
requires the authorization of the Flag State in order to take any action against a suspect vessel ${ }^{51}$. The only exception to this rule is the case in which the vessel involved in the fight against smuggling of migrants has reasonable grounds to suspect that a vessel is engaged in the smuggling of migrants by sea and is without nationality or may be assimilated to a vessel without nationality. In that situation, the officials of the State involved in the fight against smuggling of migrants may board and search the vessel and, if evidence confirming the suspicion is found, that State shall take appropriate measures in accordance with relevant domestic and international law 52 .

With regard to the constraints and limitations that international law places over the shoulders of the authorities of the flag State involved in actions against smuggling of migrants, it has to be recalled that, for instance, in the case of Hirsi Jamaa and Others v. Italy, the European Court of Human Rights (ECHR) condemned Italy for having violated Article 3 of the Convention for the Protection of Human Rights and Fundamental Freedoms ${ }^{53}$ and Article 4 of Protocol No. 4 to the Convention ${ }^{54}$. In the case, the applicants, eleven Somali nationals and thirteen Eritrean nationals, were part of a group of about two hundred individuals who left Libya aboard three vessels with the aim of reaching the Italian coast. However, on 6 May 2009, when the vessels were 35 nautical miles south of Lampedusa, they were intercepted by three ships from the Italian Revenue Police and the Coastguard and afterwards transferred onto Italian military ships and returned to Tripoli ${ }^{55}$. In its judgment of 23 February 2012, the ECHR considered " $[\ldots]$ that, by transferring the applicants to Libya, the Italian authorities, in full knowledge of the facts, exposed them to treatment proscribed by the Convention" 56 .

Turning to the Operation Sophia, as we have seen above, the UNSC Resolution 2240 provided the legal basis to implement some of the

51 See Protocol against the Smuggling of Migrants by Land, Sea and Air, supplementing the United Nations Convention against Transnational Organized Crime, Article 8, paras. 1-7.

52 See: Ibid., Article 8, para. 7. Regarding the Protocol see: Jean-Pierra Gauci and Patricia Mallia, "The Migrant Smuggling Protocol and the Need for a Multi-faceted Approach: Inter-sectionality and Multi-actor Cooperation", in 'Boat Refugees' and Migrants at Sea: A Comprehensive Approach Integrating Maritime Security with Human Rights, ed. by Violeta Moreno-Lax and Efthymios Papastavridis (Human Rights and Humanitarian Law E-Books Online, Brill, 2017): 117-144.

53 According to which no one shall be subjected to torture or to inhuman or degrading treatment or punishment.

${ }^{54}$ Which provides that collective expulsion of aliens is prohibited.

55 European Court of Human Rights, case of Hirsi Jamaa and Others v. Italy (Application no. 27765/09), Judgment of 23 February 2012, paras. 9-11.

56 Ibid., para. 137. 
measures foreseen by the Council of the EU in its Decision (CFSP) $2015 / 778$ and, of course, gave to it an important political endorsement ${ }^{57}$. Nevertheless, the UNSC Resolution falls short of authorizing the adoption of the extraordinary measures to fight against migrant smuggling and human trafficking established in the Decision of the Council of the EU setting up the Operation Sophia with regard to the waters and inland territory of Libya.

Taking into account that the situation remains extremely serious, based on UNSC Resolution 2292 (2016) on the arms embargo on Libya ${ }^{58}$, the Council of the EU, by its Decision (CFSP) 2016/993 of 20 June 2016, amended its previous Decisions setting up the military operation in the Mediterranean with a view to adding two new supporting tasks of Sophia: first, to assist in the development of the capacities and in the training of the Libyan Coast Guard and Navy in law enforcement tasks at sea and, second, to contribute to information sharing and implementation of the UN arms embargo within its agreed area of operation ${ }^{59}$. With regard to the improving of the capacities of the Libyan Coast Guard and Navy, in the first instance that task is being implemented on the high seas in the agreed area of the operation $^{60}$. Nevertheless, it is also foreseen that in an subsequent phase that task may also be carried out in the territory, including the territorial waters, of Libya or of a host third State neighboring Libya where the Political and Security Committee so decides following an assessment by the Council of the EU on the basis of an invitation by Libya or the host State concerned, and in accordance with international law ${ }^{61}$.

On 6 October 2016, the Security Council adopted another resolution on the matter, Resolution $2312(2016)^{62}$, which extended its authorisation for member States to intercept vessels on the high seas suspected of being used for migrant smuggling or human trafficking from Libya, for a further period of one year. Nevertheless, even if the UNSC Resolution 2312 (2016) confirmed again the more ordinary measures in regard with

${ }^{57}$ In this respect see the Statement of the HR/VP Federica Mogherini on the vote of UN resolution 2240 on EU naval operation in the Mediterranean, 09/10/2015 (http://eeas europa. eu/statements-eeas/2015/151009_05_en.htm) page last visited on 7 July 2017).

58 United Nations Security Council, Resolution 2292 (2016) of 14 June 2016, S/ RES/2292(2016).

59 COUNCIL DECISION (CFSP) 2016/993 of 20 June 2016 amending Decision (CFSP) $2015 / 778$ on a European Union military operation in the Southern Central Mediterranean (EUNAVFOR MED operation SOPHIA), OJEU L 162/18, 21 June 2016.

60 Ibid., Article 2a, 2.

61 Ibid., Article 2a, 3.

62 United Nations Security Council, Resolution 2312 (2016) of 6 October 2016, S/ RES/2312 (2016). 
the international law of the sea, it did not authorize those extraordinary measures foreseen by the Council of the EU in its Decision (CFSP) 2015/778, which, we recall, included the disposal or confiscation of vessels or assets which are suspected of being used for human smuggling or trafficking, in the territory of that State.

Moreover, on 12 June 2017, by its Resolution 2357, the Security Council decided to extend the authorisations as set out in resolution 2292 for a further 12 months, until 12 June $2018^{63}$.

Therefore, as long as neither UNSC Resolution 2240 nor UNSC Resolution 2312 have authorized third States or international organizations to impose order in the waters and inland territory of a coastal State, it is imperative to count on the agreement of that coastal State. In the case under consideration the political situation of Libya impedes the presentation of the necessary accord by the national authorities to implement the naval operation in the spaces under its jurisdiction and sovereignty. Nevertheless, the signature on 17 December 2015 of the Libyan Political Agreement of Skhirat, Morocco, to form a Government of National Accord consisting of the Presidency Council and Cabinet supported by the other institutions of State including the House of Representatives and State Council was an important step forward ${ }^{64}$. It remains to be seen if that agreement has arrived on time to avoid the inefficacy of the naval operation of the EU with regard to the waters and inland territory of Libya.

Regarding the outcomes of the naval Operation Sophia, until 31 January 2017, it is reported, officially, to have contributed to the saving of 32081 migrants, among whom 1888 children, even if this was never among its main goals ${ }^{65}$, but it cannot be forgotten that every vessel has an obligation to render assistance to those in distress at sea without regard to their nationality, status or the circumstances in which they are found ${ }^{66}$. At the same time, until July 2017, 109-suspected smugglers and traffickers have been apprehended and 422 boats have been removed from criminal organisations' availability. As contribution to the enforcement of the UN arms embargo, the operation carried out 530 events in accordance with

63 United Nations Security Council, Resolution 2357 (2017) of 12 June 2017, S/ RES/2357 (2017).

${ }^{64}$ In that respect see United Nations Security Council, Resolution 2259 (2015) of 23 December 2015, S/RES/2259 (2015).

${ }^{65}$ See: https://eeas.europa.eu/csdp-missions-operations/eunavfor-med/19518/operationsophia-package-2-libyan-navy-coast-guard-and-libyan-navy-training-launched-today_en, page last visited on 5 July 2017.

${ }^{66}$ See, for instance: UNCLOS Article 98(1), or the 1974 International Convention for the Safety of Life at Sea (SOLAS Convention) regulation V/33.1). 
UNSCR 2292 (2016) and among them, 45 friendly approaches, 7 flag enquiries and two inspections ${ }^{67}$.

In this regard, however, it has to be noted that during the first two years of the Operation Sophia, some questioned its efficacy, since many similar activities were already undertaken by the Italian authorities before the launching of the European naval operation. Even if with the new developments Sophia is already achieving some results when it comes to fighting against criminality ${ }^{68}$, sceptics will need to wait until the third phase, and the most powerful in military terms ${ }^{69}$, in order to note a real difference with the traditional activities of the Italian coastguards in the zone $^{70}$. In any case, what seems remarkable is the number of Member States of the EU taking part in the operation and the extent of their

${ }^{67}$ See: Press Release, EUNAVFORMED operation SOPHIA seizes weapons on board a vessel in International waters, https://eeas.europa.eu/csdp-missions-operations/eunavformed/25373/eunavformed-operation-sophia-seizes-weapons-board-vessel-internationalwaters_en, page last visited on 5 July 2017.

${ }^{68}$ It goes without saying that, as we have already underlined in this same section, in this article we are considering only the achievements of Sophia regarding its own objectives and in the context of the cooperation of EU Member States in military matters. However, Operation Sophia has raised many concerns with regard to refugee law or human rights law. In this sense see, for instance: Human Rights Watch, EU Policies Put Refugees at Risk. An Agenda to Restore Protection, 23 November 2016: https://www. hrw.org/news/2016/11/23/eu-policies-put-refugees-risk, page last visited on $11 \mathrm{July}$ 2017. In the same direction, the Director General of the International Organisation for Migration, William Lacy Swing, while paying tribute to the work of Italy's maritime forces during the operation Mare Nostrum and adding that rescue at sea operations should continue, he nevertheless noted that "Rescue at sea cannot, however, be the only solution. Alternatives must be offered to those who risk their lives at sea, and the most important one is to provide legal channels to Europe for migrants seeking international protection", see: International Organisation for Migration, IOM Applauds Italy's Life-Saving Mare Nostrum Operation: "Not a Migrant Pull Factor", Press release, 31 October 2014, see: https://www. iom.int/news/iom-applauds-italys-life-saving-mare-nostrum-operation-not-migrant-pullfactor, page last visited on 11 July 2017.

${ }^{69}$ For instance, see the evidence produced by some witness during the inquiry into the effectiveness of naval Operation Sophia carried out by the Parliament of the United Kingdom: Parliament of United Kingdom, EU External Affairs Sub-Committee, EU Naval Force - Mediterranean (Operation Sophia) inquiry, Examination of Witness, Evidence Session No. 3 Heard in Public Questions 31 - 53, Thursday 10 March 2016, evidence of Mr Peter Roberts and Mr Patrick Kingsley; or Evidence Session No. 4 Heard in Public Questions 54 - 68, Thursday 17 March 2016, oral evidence, Q57 Earl of Oxford and Asquith.

70 As it was already highlighted, the Director General of the International Organisation for Migration applauded the operation Mare Nostrum because thank to the efforts of the Italian maritime forces more than 150,000 people had arrived safely in Europe, see: International Organisation for Migration, IOM Applauds Italy's Life-Saving Mare Nostrum Operation: "Not a Migrant Pull Factor", document quoted above. 
combined contribution. Indeed, the contribution reaches the number of 25 Member States, meanwhile the fleet deployed is made up of 6 vessels together with 7 air assets ${ }^{71}$.

\section{From the naval operations of the EU to a Security and Defence Union, passing through the Permanent Structures Cooperation}

In the previous section, we have seen that both naval operations, Atalanta and Sophia, fall within the tasks defined in Article 43 (1) TEU, more precisely they can be categorised as humanitarian and rescue tasks as well as tasks of combat forces in crisis management, including peacemaking and post-conflict stabilisation. Even if Sophia was conceived to carry more muscle than her sister Atalanta, at least at the beginning of the latter's operation, both fall short of war-fighting or openly coercive operations, something in common with the rest of CSDP operations until now. According to Thierry Tardy, nothing seems to prevent theoretically the EU from engaging itself in peace enforcement operations because these operations could be included in the broader sense of the reference to "[...] tasks of combat forces in crisis management, including peace-making [...]" of Article 43 (1) TEU, but the CSDP has so far been implemented without having recourse to peace enforcement ${ }^{72}$; opinion that has been shared by other authors ${ }^{73}$.

Nevertheless, the relevant number of Member States to have participated in both naval operations shows the will and capability of those States to fulfil, within the framework of the EU, relevant missions for the international peace and security, and to provide therefore a lesson for the future of CSDP or, why not?, for the implementation of a Security and Defence Union. The slightly augmented elements of peace enforcement measures foreseen for the more advanced phases of Atalanta and Sophia go also in that direction.

71 See: https://eeas.europa.eu/csdp-missions-operations/eunavfor-med/3790, page last visited on 6 July 2017.

72 See Thierry Tardy, "CSDP in the evolving crisis management architecture" in CSDP in action -What contribution to International Security? ed. by Tardy, Chaillot Papers 134, EU Institute for Security Studies, (2015): 23.

${ }^{73}$ In the words of professor Panos Koutrakos in 2013, “[...] the military operations of the Union so far illustrate a lack of ambition". See: Koutrakos, The EU Common Security...129. In that sense see also: Patrice Sartre, "Les operations et missions extérieures de l'Éurope: historique et bilan", in L'autonomie stratégique de l'Union européenne : perspectives, responsabilité, ambitions et limites de la défense européenne, ed. by Nicola Clinchamps and Pierre-Yves Monjal (Bruxelles: Larcier, 2015), 119-121. 
The history of European integration has demonstrated that progression cannot move too quickly, that the advancements have to be done step by step, especially more so in the domains of defence and security than in other domains, as it was shown with the failure of the Treaty of 27 May 1952 Constituting the European Defence Community, "supranational in character, consisting of common institutions, common armed Forces and a common Budget" 74 . Thus in order to achieve a Security and Defence Union there is a long way ahead and the EU cannot rush or burn out its phases too quickly. In any case, there is a lot of space to gain within the possibilities opened for CSDP with the Lisbon Treaty.

\section{The time for the Permanent Structured Cooperation has come}

One step forward is to set up the PESCO anticipated in Article 42.2 and 46 of TEU and developed in Protocol No 10 annexed to the Treaty. According to these provisions, it is foreseen that certain EU countries could strengthen their cooperation in military matters by creating permanent structured cooperation ${ }^{75}$. The Lisbon Treaty established two conditions to be fulfilled by the interested States: first, those States might intensively develop defensive capacities through the development of national contributions, and also through their participation in multinational forces, European equipment programmes, and in the general activities of the European Defence Agency ${ }^{76}$. The second condition to

${ }^{74}$ Article 1 of the Treaty Constituting the European Defence Community of 27 May 1952. For an historical analysis of the European Defence Community see: Edward Fursdon, The European Defence Community -A History (London: Macmillan Press, 1980). For a more integrated analysis see: Koutrakos, The EU Common Security...5-9.

75 Moliner González also see the PESCO as an element in the path towards a Common Defence: Juan A. Moliner González, "La Cooperación Esctructurada Permanente como factor de transformación de las estructuras de seguridad y defensa", in La Cooperación Estructurada Permanente en el marco de la Unión Europea, Documentos de Seguridad y Defensa 42, Centro de Estudios de la Defensa Nacional (2011): 29-30.

${ }^{76}$ Moreover, notwithstanding certain vagueness in the legal rules concerning permanent structured cooperation, it is possible to distinguish some principles which will govern the functioning of the mechanism. In the first instance, the system is completely open to the participation of any Member State which will fulfil the criteria foreseen in Article 46 (1) TEU and want to take part in it, either at the beginning or later. Furthermore, the participating States remain free to withdraw from it at any moment. Second, every participating State must fulfil the criteria and make the necessary commitments constantly. If it fails to do so at any point, the Council may suspend the participation of the State concerned. Third, the criteria advanced in Article 46 (1) TEU and set out in Article 2 of the Protocol on Permanent Structured Cooperation are not fixed once and forever, due to the fact that the requirements related to military capabilities may evolve depending on technical and financial elements, 
fulfil in order to reach, if wanted, the PESCO, was that those interested States might acquire the capacity by 2010 to supply combat units and support logistics for the tasks referred to in article 43 TEU within a very short period of time.

However, the end of the cold war weakened the sense of risk and urgency that underpinned the efforts of the Member States in the field of defence, something that has worsened due to the financial crisis that the world and particularly Europe have endured in the last years after the enactment of the Lisbon Treaty. According to a report by the International Institute for Strategic Studies, we are now witnessing a degree of defence budgetary stabilisation in Europe for the first time since the 2008 financial crash, where real budgetary outlays - which had been declining by an average of around $2 \%$ annually since the crisisstabilised in $2015^{77}$.

It is obvious that the acquisition of the capacity by 2010 to supply combat units and support logistics for the tasks referred to in article 43 TEU within a very short period of time, has not been among the priorities of the Member States ${ }^{78}$. As Panos Koutrakos has put it, this phenomenon "[...] suggests a considerable disjunction between the grand rhetoric about the Union's international role which characterizes the official documents on European security and defence, and the practice of the Member States about dealing with the practical underpinning of that role"79. In view of the above, it appears that, until recently, the treaty provisions conceived to implement the PESCO had remained a dead letter ${ }^{80}$.

In any case, that so many Member States are implied in the naval operations Atalanta and Sophia and that currently, 27 States, all EU Member States except Denmark, participate in the European Defence Agency, makes the first requisite of the permanent structured cooperation less unachievable, if desired.

as well as the geopolitical situation. On this matter see: Koutrakos, The EU Common Security...74-76.

77 See The Military Balance 2016. Further Assessments, The International Institute for Strategic Studies (2016): 1-2.

${ }^{78}$ On this point see: Koutrakos, The EU Common Security...99-100.

79 See: Ibid., 251-252.

80 In that sense see, for instance: Antonio Missiroli, "Foreword"...5; see also: Miguel Ángel Ballesteros Martín, "Evolución y futuro de la política común de seguridad y defensa de la Unión Europea", Revista de Estudios Europeos 61 (2013): 19-20; and also: Sven Biscop and Jo Coelmont, "Military CSDP : the Quest for Capacibility", in The Routledge Handbook of European Security, ed. by Sven Biscop and Richard G. Whitman (London: Routledge, 2013): 85 . 
However, as it was stated above, after the Brexit vote, without the veto of the United Kingdom, the time has come for setting up the PESCO, as the new developments are showing. Indeed, on 22 June 2017 the European Council announced its agreement on the need to launch an inclusive and ambitious PESCO as soon as possible ${ }^{81}$. Therefore, on 13 November 2017, ministers from 23 Member States signed a joint notification on PESCO and handed it over to the High Representative and the Council ${ }^{82}$. On 7 December 2017, Ireland and Portugal also notified their decision to join PESCO. Thus, on 11 December 2017, the Council adopted a decision establishing PESCO and determining the list of Participating Member States ${ }^{83}$. At the same time, Member States participating in PESCO also adopted a declaration identifying an initial list of 17 projects to be undertaken under PESCO, which are expected to be formally adopted by the Council of the EU in 2018. Those projects cover areas such as training, capability development and operational readiness in the field of defence ${ }^{84}$.

There will be other opportunities to reflect about the implementation of PESCO in the coming months, but it is important to underline from the outset that Participating Member States are going to remain at the center of the decision making process while coordinating with the High Representative.

In any case, a real measure, already taken, has been the implementation of a European Defence Fund in June 2017, which was, in September 2016, announced by the President of the European Commission and accepted by the European Council in December $2016^{85}$, with the aim of helping Member States develop and acquire key strategic defence capabilities more quickly, jointly and in a more cost effective way.

${ }^{81}$ European Council conclusions on security and defence, 22 June 2017, para. 8.

82 See: http://www.consilium.europa.eu/media/31511/171113-pesco-notification.pdf, page last visited on 12 December 2017.

83 COUNCIL DECISION establishing Permanent Structured Cooperation (PESCO) and determining the list of Participating Member States, see: http://www.consilium.europa.eu/ media/32000/st14866en17.pdf.

The initial participating Member States are: Austria, Belgium, Bulgaria, Czech Republic, Croatia, Cyprus, Estonia, Finland, France, Germany, Greece, Hungary, Italy, Ireland, Latvia, Lithuania, Luxembourg, the Netherlands, Poland, Portugal, Romania, Slovenia, Slovakia, Spain and Sweden.

${ }^{84}$ See: http://www.consilium.europa.eu/media/32020/draft-pesco-declarationclean-10122017.pdf, page last visited on 12 December 2017.

85 European Council conclusions on security and defence, 15 December 2016, para. 12. 


\section{Which would be the remaining steps beyond the Permanent Structured Cooperation?}

Beyond the PESCO, the European Council should define a roadmap with practical and realistic steps to move, by stages ${ }^{86}$. Together with the changes that need to be put into practice in order to reach the PESCO, which imply pooling and sharing military capabilities, it will be necessary to implement institutionally and procedurally relevant defence reforms in EU law ${ }^{87}$.

In particular, it seems to me that the derogations to EU law regarding the free movements of goods (Article 36 Treaty on the Functioning of the European Union (TFEU)), persons (Articles 45 (3) and 52 TFEU) and capital (Article 65 TFEU) of the common market based on Member States public security, or the even more special derogation from EU law which supposes the exception laid down in Article 346 TFEU regarding arms, munitions and war materials ${ }^{88}$, need to be rethought ${ }^{89}$.

${ }^{86}$ For instance, according to the group of experts of the Centre for European Policy Studies Task Force on European security and defence, those steps would consist on a number of concrete policy actions across three directions: 1) strategic upgrade; 2) reform of institutions, procedures and financing; and 3) capabilities and industrial harmonization. In that respect see: "More Union in European Defence", Report of a CESP task force, Centre for European Policy Studies (2015): 14-16. Over the role of the strategy in the future of the European integration in the field of defence see, for instance: Manuel Muniz, "Strategy and Its Role in the Future of European Defence Integration", Istituto Affari Internazionali Working Papers, 1330 (2013).

${ }^{87}$ For instance, according to Miguel Ángel Ballesteros, the absence of a permanent headquarter is at present the more serious problem which encounters the CSDP. See on that matter: Miguel Ángel Ballesteros Martín, "Evolución y futuro...17.

88 " 1 . The provisions of the Treaties shall not preclude the application of the following rules: (a) no Member State shall be obliged to supply information the disclosure of which it considers contrary to the essential interests of its security; (b) any Member State may take such measures as it considers necessary for the protection of the essential interests of its security which are connected with the production of or trade in arms, munitions and war material; such measures shall not adversely affect the conditions of competition in the internal market regarding products which are not intended for specifically military purposes. 2. The Council may, acting unanimously on a proposal from the Commission, make changes to the list, which it drew up on 15 April 1958, of the products to which the provisions of paragraph 1(b) apply". Over the European defence market see: Stéphane Rodrigues, "Le marché européen de la défense : entre coopération et harmonisation ", in L'autonomie stratégique de l'Union européenne : perspectives, responsabilité, ambitions et limites de la défense européenne, ed. by Nicola Clinchamps and Pierre-Yves Monjal (Bruxelles: Larcier, 2015) : 137-161.

${ }^{89}$ On the matter concerning the institutional frame in regard to CSDP operations see: Carmen Gebhard, "The Institutional Nature of the EU as a Global Conflict Manager", in The European Union as a Global Conflict Manager, ed. by Richard G. Whitman, and Stefan Wolff (Abingdon: Routledge, 2012): 23-32. 
Additionally, if the Member States confer competence to the EU to set up a Security and Defence Union, further reforms may need to be implemented in the EU's decision-making process. It is well known that nowadays the European Parliament plays a limited role in Common Foreign and Security Policy (CFSP) and that the situation is even worse if we look particularly at the domain of CSDP. The European Parliament lacks any formal power in the adoption of CFSP decisions, since legislative acts are excluded from $\mathrm{CFSP}^{90}$. In that respect, the Council of the European Union should retain its significant role in the formation of the law through special legislative procedures, taking into consideration the sensibility of the Member States concerning the defence issues. For me, to adopt decisions in the field of defence through the ordinary legislative procedure seems to be too radical to start with.

Finally, concerning the role of the Court of Justice of the European Union, at the present stage of European integration, the jurisdiction of the Court of Justice of the European Union is generally excluded with respect to CFSP and CSDP provisions and acts adopted on the basis of those provisions, by virtue of Article 24 TEU. Nevertheless, the Treaties acknowledge two express exceptions. First, in accordance with Article 40 TEU, the content of an act adopted in the context of the CFSP can be reviewed by the Court of Justice in order to ascertain whether that act does not affect the other competences of the EU institutions. Second, according to Article 275 (2) TFEU, the Court of Justice has jurisdiction to review the legality of "decisions providing for restrictive measures against natural or legal persons adopted by the Council on the basis of Chapter 2 of Title V of the Treaty on European Union"91. Furthermore, the Court has jurisdiction

90 On the role of the European Parliament in the CSDP see, for instance, Nicola Clinchamps, "La PSDC et le Parlement européen à la lumière du Traité de Lisbonne", in L'autonomie stratégique de l'Union européenne : perspectives, responsabilité, ambitions et limites de la défense européenne, ed. by Nicola Clinchamps and Pierre-Yves Monjal (Bruxelles: Larcier, 2015): 55-72.

${ }^{91}$ In this regard there is an extensive case-law of the European Union Courts, see for instance: judgments in Commission and Others v Kadi, C-584/10 P, C-593/10 P and C-595/10 P, EU:C:2013:518; Council v Manufacturing Support \& Procurement Kala Naft, C-348/12 P, EU:C:2013:776; Bank Melli Iran v Council, T-35/10 and T-7/11, EU:T:2013:397; and Hassan v Council, T-572/11, EU:T:2014:682). However, these exclusions must be interpreted narrowly, as the Court of Justice of the European Union has sustained in its jurisprudence. For instance, recently, the Court of Justice argued that; "[...]41 According to the final sentence of the second subparagraph of Article 24(1) TEU and the first paragraph of Article 275 TFEU, the Court does not, in principle, have jurisdiction with respect to the provisions relating to the CFSP or with respect to acts adopted on the basis of those provisions (judgment in Parliament v Council, C-658/11, EU:C:2014:2025, paragraph 69)." "42 Nevertheless, the final sentence of the second subparagraph of 
regarding the national security exception to the freedoms of common market that we have seen before and concerning the exception to EU law provided for in Article 346 TFEU regarding arms, munitions and war materials $^{92}$. Thus, if the Member States decide in the future to increase the competence of the EU in defense matters, the Court of Justice will see its jurisdiction in that field reinforced accordingly.

For me, it would be extremely convenient for the Court to control the decisions of the EU institutions involved in deliberations regarding acts that implicate the use of force, the prohibition of which can be considered as a norm of jus cogens or imperative in international law. Remember that, as it arises clearly from its jurisprudence, the Court of Justice can exercise its judicial review in order to determine " $[\ldots]$ whether the superior rules of international law falling within the ambit of jus cogens have been observed" 93 even in the case of the decisions of the UNSC.

It goes without saying that all these changes require a transformation of political mentalities in the EU in order to build a solid European defence.

Article 24(1) TEU and the first paragraph of Article 275 TFEU introduce a derogation from the rule of the general jurisdiction which Article 19 TEU confers on the Court of Justice to ensure that in the interpretation and application of the Treaties the law is observed, and they must, therefore, be interpreted narrowly (judgment in Parliament v Council, C-658/11, EU:C:2014:2025, paragraph 70)" (Judgment of the Court (Fifth Chamber) of 12 November 2015. Elitaliana SpA v Eulex Kosovo). For a review of the jurisprudence of the Court concerning the distinction among CSDP and other strands of external action or in regard to the exception to the freedoms of common markets based on national security, see: Koutrakos, The EU Common Security...210-282.

92 To finish the role of the Institutions in CFSP, mention should be made to the Commission, even though its implication within the CFSP is minimal and ill defined. Together with the High Representative, the Commission may make joint proposals to the European Council on the strategic interests of the Union. On the other hand, the Commission may support proposals by the High Representative to the Council, yet this joint right of initiative is not very relevant so far as it is shared with any Member State.

93 "The indirect judicial review carried out by the Court in connection with an action for annulment of a Community act adopted, where no discretion whatsoever may be exercised, with a view to putting into effect a resolution of the Security Council may therefore, in some circumstances, extend to determining whether the superior rules of international law falling within the ambit of jus cogens have been observed, in particular, the mandatory provisions concerning the universal protection of human rights, from which neither the Member States nor the bodies of the United Nations may derogate because they constitute 'intransgressible principles of international customary law' (Advisory Opinion of the International Court of Justice of 8 July 1996, The Legality of the Threat or Use of Nuclear Weapons, Reports 1996, p. 226, paragraph 79; see also, to that effect, Advocate General Jacobs's Opinion in Bosphorus, paragraph 239 above, paragraph 65)". See: Case T-306/01, Ahmed Ali Yusuf and Al Barakaat International Foundation v Council of the European Union and Commission of the European Communities, Judgment of the Court of First Instance (Second Chamber, Extended Composition), 21 September 2005, para. 282. 
The steps forward are clear and feasible. Yet it remains to be seen whether or not the Member States really want to go in that direction ${ }^{94}$, taking into account their reluctance until now to collaborate deeply in the field of defence ${ }^{95}$.

\section{Conclusion}

The two naval operations set up until now by the EU, Atalanta and Sophia, have demonstrated a growing level of consensus and willingness by Member States, a great number of which participating in both operations. Furthermore, and more clearly in the case of Atalanta but also in the first stages of Sophia, it can be said that these CSDP activities have been highly successful, taken into consideration the level of accomplishment of their respective goals ${ }^{96}$. Against this assertion some could argue that neither Atalanta nor Sophia are facing extremely powerful enemies. Nevertheless, the relevant fact is that both naval operations underscore the possibilities of the European cooperation in such a delicate field as security ${ }^{97}$.

${ }^{94}$ In this sense, see also: Moliner González, "La Cooperación Estructurada Permanente...", 31 .

95 As Antonio Missiroli has recently put it, "While the long-lasting decline in collective defence spending by Europeans seems to have recently come to a temporary halt (following also commitments made in the NATO framework), the lack of major cooperative projects in the defence industrial domain and the growing difficulty to agree on ambitious actions and reforms are marking an impasse in a policy area that, until a few years ago, was among the most promising in terms of closer integration and convergence of efforts among Europeans." See: Antonio Missiroli, "Foreword"...5.

${ }^{96}$ Let me insist again that in this article we are considering only the achievements of Operation Sophia with regard to its own objectives and in the context of the cooperation of EU Member States in military matters, but, at the same time, it cannot be forgotten that Sophia has raised many concerns with regard to refugee law or human rights law (see above in the section about the Operation Sophia).

97 I agree with Professor Miguel Acosta when he said that, with the Petersberg operations "[...] the EU has improved its internal credibility among its own States, in that it has demonstrated its capacity to effectively manage these sensitive matters. This credibility is an important step towards achieving a political union within the integration process". See: Miguel Acosta Sánchez, The EU's military crisis management operations: Peterberg tasks and international peace (Saarbrücken: LAP Lambert Academic Publishing, 2011), 193. In my opinion those words can also be applied to the two naval operations. Neverthelees, that point of view is not completely shared by Annemarie Peen Rodt, as long as she thinks that: "In sum, the EU's performance in military conflict management has been a relative success from the point of view of the Union, but more humble with regard to the management of the conflict situations on the ground", see: Peen Rodt, "EU performance in military conflict... 186. 
Having shown its potential, the launching of naval operations in crisis management could be seen as a step forward in the creation of a Security and Defence Union. That path has to be pursued slowly; as was clearly shown in the case of the adoption of the Treaty constituting the European Defence Community in 1952, rapidity here can lead to abysm.

Therefore, the next step in European integration regarding security matters can be the implementation of the PESCO anticipated in Article 42.2 and 46 of TEU and developed in Protocol No 10 annexed to the Lisbon Treaty, which after some years of oblivion seems now to become a reality once the United Kingdom, a traditional antagonist regarding the European integration in defence matters, has recently announced its decision to leave the $\mathrm{EU}^{98}$. We recall that, on 11 December 2017, the Council of the EU adopted a decision establishing PESCO and determining the list of Participating Member States. The fact that also very recently, in June 2017, a European Defence Fund has been created with the aim of facilitating the acquisition of defence capabilities will pave the way for the implementation of the PESCO. That achievement would be the landmark that would generate the nucleus from which a Security and Defence Union can emerge.

In any case, today a Security and Defence Union in the EU is neither utopian nor a nightmare. The European Parliament itself, in its Resolution of 21 January 2016 on the mutual defence clause (Article 42(7) TEU), affirmed that the activation of the mutual assistance clause was a unique opportunity "[...] to establish the grounds for a strong and sustainable European Defence Union;" 99 and added that "[...]only with an autonomous security and defence capability will the EU be equipped and ready to face the overwhelming internal and external security threats and challenges" 100 .

A constant in the history of European integration is that the greatest steps forward have followed big crisis. Only in front of disgrace can States start to think positively about the prospects of walking together rather than alone. It would be an extraordinary achievement if the will of the Member States to move forward in the direction of the creation of a Security and Defence Union comes out of conviction and not out of destruction.

${ }^{98}$ In this respect, see the reference we made in the introduction about the position of the UK.

99 European Parliament resolution of 21 January 2016 on the mutual defence clause (Article 42(7) TEU) (2015/3034(RSP)), para. 18. See: http://www .europarl.europa.eu/sides/ getDoc.do?type=TA\&language $=$ EN\&reference $=P 8-T A-2016-0019$, page last visited on 7 July 2017.

100 Ibid. 
Perhaps the Brexit could bring with it some positive aspects after all, and with respect to a more integrated defence in Europe it could represent a turning point.

It's up to the remaining 27 Member States to decide whether or not they want to give more competences or not to the $\mathrm{EU}$ in defence matters.

At least, what is completely sure is that the time for truth has arrived. In the coming months we will see whether Sven Biscop was right or not when he pointed out that "[ $\mathrm{t}] \mathrm{he}$ problem of European defence is that it does not work with the United Kingdom, but would not work without it either" ${ }^{\prime 101}$.

\section{About the author}

Professor Espaliú got a scholarship from the Spanish Ministry of Education (1995-1998), he has been Lecturer in the University of Navarre (Spain) (1998-2000), Legal Officer of the International Court of Justice (2000-2006) and Ramón y Cajal Researcher in the University of Córdoba (Spain) (2007-2012). At present, he is Associate Professor in Public International Law and European Union Law at the International University of Catalonia (UIC, Barcelona) (Spain); Vice-Dean for Academic Affairs and Head of the International Law Department at the Faculty of Law (UIC, Barcelona) ; Director of the Charlemagne Institute of European Studies (UIC, Barcelona). He coordinates a research group recognized by the Government of Catalonia and he has participated in a dozen regional or national research groups. His research focuses in the following lines: Peaceful Settlement of International Disputes, Law of the Sea, International Subjectivity, Use of Force, Slavery and European Security. He obtained, among others, the acreditation as Associate Professor (ANECA) in 2011 and Full Professor (AQU) 2015. Furthermore, he has been awarded two six-years research periods (CNAI) and two six-years research periods (AQU). Regarding European Law, he has published, among others, the following articles: A Reflection on the Participation of Individuals in the Creation of European Law through the European Citizens' Initiative and its Scope in International Law, Cuadernos Europeos de Deusto, N. . 54, 2016, pp. 181-202; The EU response to the Paris terrorist attacks and the reshaping of the rights to self-defence in International Law, Spanish Yearbook of International Law, N. . 20, 2016, pp. 183-207.

101 Biscop, “The UK and European Defence: Leading or Leaving?...”, 1297. 


\section{Sobre el autor}

El profesor Espaliú ha sido becario de investigación de Ministerio de Educación (1995-1998), profesor de la Universidad de Navarra (19982000), Letrado de la Corte Internacional de Justicia (2000-2006) e investigador Ramón y Cajal en la Universidad de Córdoba (2007-2012). En la actualidad, es profesor agregado de Derecho Internacional Público y de la Unión Europea en la Universitat Internacional de Catalunya (UIC, Barcelona); Vicedecano de Ordenación Académica y Jefe del área de Derecho Internacional de la Facultad de Derecho de la UIC y Director del Instituto Carlomagno de Estudios Europeos de la UIC. Es coordinador de un grupo de investigación (SGR de la Generalitat de Catalunya) y ha participado en una decena de proyectos de investigación nacionales y regionales. Sus líneas de investigación principales son el arreglo pacífico de las controversias internacionales, el derecho del mar, la subjetividad internacional, el uso de la fuerza, la esclavitud y la seguridad europea. Ha obtenido, entre otras, la acreditación de profesor titular de ANECA en 2011 y la acreditación de catedrático (recerca avançada) de la AQU en 2015. También cuenta con dos sexenios de investigación del CNAI y dos sexenios de investigación de AQU. En materia de Derecho Europeo, entre otros trabajos, ha publicado: A Reflection on the Participation of Individuals in the Creation of European Law through the European Citizens' Initiative and its Scope in International Law, Cuadernos Europeos de Deusto, N. ${ }^{\circ}$ 54, 2016, pp. 181-202; The EU response to the Paris terrorist attacks and the reshaping of the rights to self-defence in International Law, Spanish Yearbook of International Law, N. ${ }^{\circ} 20,2016$, pp. 183-207. 


\section{Derechos de autor}

Los derechos de autor (para la distribución, comunicación pública, reproducción e inclusión en bases de datos de indexación y repositorios institucionales) de esta publicación (Cuadernos Europeos de Deusto, CED) pertenecen a la editorial Universidad de Deusto. El acceso al contenido digital de cualquier número de Cuadernos Europeos de Deusto es gratuito inmediatamente después de su publicación. Los trabajos podrán leerse, descargarse, copiar y difundir en cualquier medio sin fines comerciales y según lo previsto por la ley; sin la previa autorización de la Editorial (Universidad de Deusto) o el autor. Así mismo, los trabajos editados en CED pueden ser publicados con posterioridad en otros medios o revistas, siempre que el autor indique con claridad y en la primera nota a pie de página que el trabajo se publicó por primera vez en $C E D$, con indicación del número, año, páginas y DOI (si procede). Cualquier otro uso de su contenido en cualquier medio o formato, ahora conocido o desarrollado en el futuro, requiere el permiso previo por escrito del titular de los derechos de autor.

\section{Copyright}

Copyright (for distribution, public communication, reproduction and inclusion in indexation databases and institutional repositories) of this publication (Cuadernos Europeos de Deusto, CED) belongs to the publisher University of Deusto. Access to the digital content of any Issue of Cuadernos Europeos de Deusto is free upon its publication. The content can be read, downloaded, copied, and distributed freely in any medium only for non-commercial purposes and in accordance with any applicable copyright legislation, without prior permission from the copyright holder (University of Deusto) or the author. Thus, the content of $C E D$ can be subsequently published in other media or journals, as long as the author clearly indicates in the first footnote that the work was published in $C E D$ for the first time, indicating the Issue number, year, pages, and DOI (if applicable). Any other use of its content in any medium or format, now known or developed in the future, requires prior written permission of the copyright holder. 